\title{
MEANS OF DETERMINING WHEN TREBLE DAMAGES ARE RECOVERABLE FOR A LOSS DUE TO A VIOLATION OF THE ANTITRUST LAWS
}

Section 4 of the Clayton $\mathrm{Act}^{1}$ provides for recovery of treble damages by a person $^{2}$ when "injured in his business or property by anything in violation of the antitrust laws." 3 Recently, the Court of Appeals for the Seventh Circuit, in Congress Building Corp. v. Loew's, Inc., ${ }^{4}$ came close to saying that proof of any kind of loss, if the result of an antitrust violation, is proof that a person has been so "injured." As the primary purpose of section 4 is to ensure more effective enforcement of the antitrust laws, this conclusion would seem at least at first glance to be justifiable. ${ }^{B}$ Certainly those who are financially affected are the ones most likely to be aware of any violations, and in consequence the more losses which are recoverable under section 4, the more hikely it is that an illegal conspiracy will be broken. But the notion that proof of a loss is alone proof of an "injury" constitutes a significant departure from most of the prior decisions. ${ }^{7}$ This comment shall attempt to determine whether this approach to determining when a person is "injured" within the meaning of section 4 is judicially supportable, or warranted with respect to the objectives of the antitrust laws as a whole.

\section{DIRECT AND INDIRECT IOSSES DISTINGUISHED}

By its terms, section 4 allows recovery for a loss only when the loss constitutes damages in the sense of measuring the extent to which the plaintiff has been injured by the violation complained of. ${ }^{8}$ As a result, proof of a loss due to an antitrust violation is not necessarily proof of an "injury." Assuming that the defendant has violated the antitrust laws, the additional element required to establish an "injury" is that the loss be the result of a violation of a legal right which by virtue of the

138 STAT. 731 (1914), 15 U.S.C. \$ 15 (1952).

2 The term "person" has been held to comprise not only private corporations and natural persons, but state governments as well. Georgia v. Pennsylvania R.R., 324 U.S. 439 (1945). But the term does not allow treble damage actions by the United States. United States v. Cooper Corp., 312 U.S. 600 (1941).

3 This section superseded Section 7 of the Sherman Act, 26 STAT. 210 (1890), the provisions of which were substantially identical except limited in operation to violations of the act of whicl they were a part.

4246 F.2d 587 (7th Cir. 1957).

- See text at note 51 infra.

${ }^{8}$ See 51 Cong. Rec. 16319 (1914). The treble damage provision was inserted in Section 7 of the Sherman Act not only to ensure adequate recompense, but to provide a sufficient encouragement for bringing the action. The provision was inserted in response to criticism of the bill on the ground that no civil suits would be brought in view of the unlikelihood of their being successful. It should also be noted that there is no minimum amount in controversy requirement as a prerequisite to relief. See note 8 infra.

7 There were additional facts in the Congress decision which would appear to warrant its result without resort to the argument that any loss due to a violation of the antitrust laws is jecoverable under Section 4. Moreover, the decision gives some indication that had these facts not been present, the result might have been different. The reasoning of the court is not founded on these facts, however, but rather on the theory under examination. See note 61 infra.

8 Section 4 provides as follows: "Any person who shall be injured in his business or property by reason of anything forbidden in the antitrust laws may sue therefor in any district court of the United States in the district in which the defendant resides or is found or has an agent, without respect to the amount in controversy, and shall recover threefold the damages by him sustained, and the cost of suit, including a reasonable attorney's fee." 
antitrust laws was vested in the plaintiff. ${ }^{\circ}$ However, the reasoning of the court in Congress implies that the right created by the antitrust laws is one entitling persons to the benefits to be derived from the conditions these laws are designed to ensure. Whether the decisions inconsistent with this approach embody an alternative theory can only be disclosed by determining what kinds of losses have been regarded by the courts as proof of "injuries," and what kinds have not.

With respect to recoverability under section 4 , the decisions have created a distinction between "direct" and "indirect" losses. Unless the kind of business affected is considered unworthy of protection, ${ }^{10}$ losses to a business due to the illegal acts of a competitor are always recoverable. ${ }^{11}$ Also, losses sustained in making purchases or sales, because of the antitrust violations of the other party to the transaction, are recoverable. ${ }^{12}$ Proof of these losses is proof of an "injury," provided the loss measures the extent to which the plaintiff is deprived of a benefit which he would have obtained had conditions of free competition prevailed. ${ }^{13}$ If it does, the plaintiff can be compensated not only for a loss in the usual sense, but the failure to realize gain as well. ${ }^{14}$ These types of losses-to competitors and to persons having dealings with a violator-shall be referred to as "direct." An "indirect" loss, on the other hand, is a loss one step removed from the antitrust violation. It is a failure to receive more orders from a business as a result of the effect on that business of the violation, or a loss in the value of, or return from an interest in that business. The distinction between "direct" and "indirect" losses is of importance because proof of the latter type of loss has not always been regarded as proof of an "injury." Where actions to recover for "indirect" losses were allowed, it was usually because of some additional factor which the court considered decisive. This can best be shown by examining the various kinds of "indirect" losses and the treatment afforded attempts to recover for them under section 4.

${ }^{9}$ In Keogh v. Chicago \& N.W. Ry., 260 U.S. 156, 163 (1922), it was stated that "injury implies violation of a legal right." Because lie was not entitled to different rates than those set by the Interstate Commerce Commission, the plaintiff was held not entitled to bring a treble damage action for excessive rates which he alleged the defendants liad induced the I.C.C. to approve.

10 Maltz v. Sax, 134 F.2d 2 (7th Cir.), cert. denied, 319 U.S. 772 (1943) (manufacturer of gambling devices).

11 This is so even though the plaintiff was a member of the conspiracy complained of. Kiefer-Stewart Co. v. Joseph E. Seagram \& Sons, Inc., 340 U.S. 211 (1951).

12 Mandeville Island Farms, Inc. v. American Crystal Sugar Co., 334 U.S. 219 (1948) (seller); Eastman Kodak Co. v. Southern Photo Materials Co., 273 U.S. 359 (1927) (buyer); Thomsen v. Cayser, 243 U.S. 66 (1917) (buyer).

13 Keogh v. Chicago \& N.W. Ry., 260 U.S. 156, 163 (1922) (see note 9 suppra); Westmoreland Asbestos Co. v. Johns-Manville Corp., 30 F. Supp. 389 (S.D.N.Y. 1939), aff'd per curiam, 113 F.2d 114 (2d Cir. 1940) (see note 22 infra).

14 In the case of a business, an operating loss consists of the amount by which costs exceed revenues for a given period. Consequently, if a firm breaks even, it has not suffered any loss in this sense. But in Bigelow v. RKO Radio Pictures, Inc., 327 U.S. 251 (1946), the plaintiff recovered as damages the amount of profits which it proved would have been realized but for the defendants' antitrust violations.

No case has been found in which recovery for operating losses was sought. But in Story Parchment Co. v. Paterson Parchment Paper Co., 282 U.S. 555 (1931), the award of the following damages was sustained: first, the difference between the prices at which the plaintiff was forced to sell its product because of price-cutting by the defendants, and the prices before the price-cutting began; second, the difference between the undepreciated cost of the production facilities and the amount received for them at a distress sale. 


\section{Losses in the Value of Stock}

Attempts to recover treble damages for the loss in value of stock have been fairly numerous. ${ }^{15}$ With one exception, they have been unsuccessful. The leading case in this area is Loeb v. Eastman Kodak Co. ${ }^{16}$ There it was held that Section 7 of the Sherman Act was not an exception to the rule that a shareholder could get redress for a loss in the value of his stock only by means of a derivative suit. This was an application of the concept of the separate legal entity of the cororation. While the loss is to the stockholder, the cause of action for the injury is vested in the corporation. ${ }^{17}$

The one case where an action to recover the loss in value of stock was allowed is United Copper Securities Co. v. Amalgamated Copper Co.18 The complaint alleged the loss was due to a conspiracy to acquire a corportion owned by the plaintiffs, in order to destroy their business, by organizing companies which would be competitors of the defendant. The plaintiffs were held to have stated a separate injury to themselves. This case can be regarded as one allowing an action to recover for a loss which in fact was "direct," as this term has been defined, because it was a business loss that was suffered by a competitor.

\section{Loss to Creditor from Inability of Debtor Business to Pay Fixed Claim}

Only twice have creditors attempted to recover under section 4 because of inabihty to collect a debt. The first attempt was made in the Loeb case, where the plaintiff was held not entitled to recover as a creditor for the same reason that he was denied recovery as a stockholder. This would seen to indicate that the cause of action for the creditor-loss was also vested in the corporation, even though creditors do not have the same rights with respect to management of the corporation as do stockholders. ${ }^{19}$ In order to bolster its decision the court gave as an additional reason for affirming the order sustaining defendant's demurrer that any "injury" to the plaintiff as a creditor was "indirect, remote, and consequential."20

16 Martens v. Barrett, 245 F.2d 844 (5th Cir. 1957) ; Peter v. Western Newspaper Union, 200 F.2d 867 (5th Cir. 1953) ; Peterson v. Borden Co., 50 F.2d 644 (7th Cir. 1931); Gerli v. Silk Ass'n of America, 36 F.2d 959 (S.D.N.Y. 1929) ; Loeb v. Eastman Kodak Co., 183 Fed. 704 (3d Cir. 1910); Gomberg v. The Midvale Co., 157 F. Supp. 132 (E.D. Pa. 1955) ; Walder v. Paramount Publix Corp., 132 F. Supp. 912 (S.D.N.Y.1955); Westmoreland Asbestos Co. v. Johns-Manville Corp., 30 F. Supp. 389 (S.D.N.Y.1939), aff'd per curiam, 113 F.2d 114 (2d Cir. 1940); Ames v. American Tel. and Tel. Co., 166 Fed. 820 (D. Mass. 1909).

Stockholders' derivative suits, to obtain a recovery for the corporation, are to be distinguished. See note 56 infra.

Also to be distinguished are actions by a stockholder who has been induced to sell his shares for less than their real value.

16183 Fed. 704 (3d Cir. 1910).

17 Coast v. Hunt Oil Co., 195 F.2d 870 (5th Cir.), cert. denied, 344 U.S. 836 (1952). In this case an action by a partner was denied on the ground that the cause of action alleged was vested in his firm which, under Louisiana law, had a separate legal entity. To the same effect is Farmers Cooperative Oil Co. v. Socony-Vacuum Oil Co., 133 F.2d 101 (8th Cir. 1942) (dismissal of action by cooperative entitled to sue in its own name affirmed, where the only injuries alleged were the losses of the individual members, defendant conceding that plaintiff was entitled to maintain an action for any injury sustained by it in its own busmess).

18232 Fed. 574 (2d Cir. 1916).

19 The "creditor injury" Inust be distinguished from the right of a creditor or trustee in bankruptcy to resort to a corporate asset consisting of a cause of action for an injury to the corporation.

20183 Fed. at 709. 
Presumably, the injury was "indirect" because the loss was. This implied that an "indirect" loss would be recoverable under section 4 but for a strict construction that created a distinction between "direct" and "indirect injuries."

The second case was Westmoreland Asbestos Co. v. Johns-Manville Corp. ${ }^{21}$ where a lessor corporation was seeking to recover for the loss to it when the lessee was driven out of business, due to the defendant's antitrust violations. The loss for which recovery was sought, however, was the value of the property, not the lost rentals. The property was suitable only for manufacturing products competitive with those of the defendant, and the plaintiff was unable to obtain a new tenant with the result that a mortgage on the property was foreclosed. In dismissing the action, the court relied on Loeb and also the fact that the proximate cause of the loss was not the antitrust violation alleged, but the mortgage foreclosure. ${ }^{22}$ This overlooked the question whether the proximate cause of the foreclosure might have been the defendant's illegal monopoly, in that it removed the possibility of finding another tenant. Under the "direct injury" rule, however, this would be immaterial because the loss was "indirect."

\section{Loss of Lessor from Failure to Obtain Greater Rental}

When seeking a tenant and negotiating as to terms of the lease, the owner of property is not a creditor, and may be said to be in the business of leasing. A failure to obtain a greater rental, due to antitrust violations, may nevertheless be an "indirect" loss. In Steiner v. 20th Century-Fox Film Corp. ${ }^{23}$ however, the loss for whicli recovery was sought was "direct," being the result of dealings with the alleged antitrust violator. The plaintiff contended that she was forced to renew the lease to the defendant, the only available tenant, for less than a reasonable percentage rental because of threats by the defendant that otherwise the theater would be relegated to a second-run position. But the loss was "indirect" in Camrel Co. $v$. Paramount Film Distributing Corp., ${ }^{24}$ an action by a lessor unable to renew a lease to its tenant for a reasonable rental, because the latter was a victim of the defendant's antitrust violations. In denying a motion to dismiss, the court gave no reason for its conclusion that an injury had been sufficiently alleged. This decision cannot be reconciled with the "direct injury" rule.

The type of loss involved in Congress was the failure of a lessor to receive a greater return under a lease entitling the plaintiff to a percentage of the gross receipts of the business conducted on the leased property. Whether such recovery is proper was first analyzed in Harrison v. Paramount Pictures, Inc., ${ }^{25}$ where an additional factor-that the lessee was alleged to be a party to the conspiracy complained of -was present. Because the lease gave the plaintiff no right to control the lessee's manner of operation of the theater, the court concluded that the lessee's relegation of the theater to an inferior exhibiting position in violation of the antitrust laws was not an injury to the plaintiff within the meaning of section $4 .{ }^{28}$ But

2130 F. Supp. 389 (S.D.N.Y. 1939), affd per curiam, 113 F.2d 114 (2d Cir. 1940).

22 The benefit which the lessor would have obtained had competitive conditions-and therofore tenants-existed would have been the incoune from the property, not its retention.

23 232 F.2d 190 (9th Cir. 1956).

241944 CCH Trade Cas. Par. 57,233 (S.D.N.Y.).

25115 F. Supp. 312 (E.D. Pa. 1953), aff'd per curiam, 211 F.2d 405 (3d Cir.), cert. denied, 348 U.S. 828 (1954).

26 The court relied on the statement in Keogh v. Chicago \& N.W. Ry., 260 U.S. 156, 163, that ". . injury imphes violation of a legal right." See note 9 sicpra. 
although no volation of the duties of a lessee was considered to have occurred, the fact remained that the plaintiff's loss was nevertheless alleged to be the result of the defendants' violation of the antitrust laws. The court disposed of this problem by resorting to the "direct mjury" rule; any "injury" shown by this "indirect" loss was too "remote" to be recoverable. ${ }^{27}$

In Productive Inventions, Inc. v. Trico Products Corp., ${ }^{28}$ the antitrust violator was a competitor of the licensee of the plamtiff's patent. The plaintiff was entitled to a percentage of the sales of the hicensee, which it alleged were suppressed by the defendant's violations. Although the court cited Harrison, the stated reason for denying relief was that the plaintiff was not "injured" at all, because not the party at whom the violation complained of was "directly aimed." 29 The basis of this reasoning was the statement that "not every financial loss due to an anti-trust violation, however remote, gives a right of action."30 Why the remoteness of the loss should make any difference was not explained, but it should be noted that this "directly aimed" test is not the same as the "direct injury" rule. The latter assumes that the plaintiff is "injured," but denies recovery because the "injury" is "indirect." The "directly aimed" test, on the other hand, involves no such assumption, since it distinguishes between a loss and an "injury." It follows that this test is not necessarily based on a strict construction of section 4 .

\section{Loss to Supplier of Directly Affected Business}

A relation to the directly affected business analogous to that created by a contract right to a percentage of gross receipts is that created by a requirements contract. Just as the sales of the directly affected business determine the income of the percentage lessor, so the sales of the customer will have a predictable effect on the volume of its requirements. The resultant orders then determine the income of the supplier having the contract. In Snow Crest Beverages, Inc. v. Recipe Foods, Inc., ${ }^{31}$ a supplier having such a contract sought to recover for the losses to it which resulted from the effect of the defendant's antitrust violations on the customer's business. The court, in granting a motion to dismiss, relied on the "direct injury" rule and made it clear that this rule was regarded as a means of restricting the application of section $4 . .^{32}$

In contrast, the opposite result had previously been reached in Karseal Corp. v. Richfield Oil Corp., ${ }^{33}$ even though the correlation between the sales of the customers and those of the supplier bringing the action was less definite. The plaintiff was a manufacturer of an automobile finish, and was complaining about the fact that the defendant did not allow any of its gasoline dealers to stock it. In order to obtain the defendant's gasoline, the dealers had to agree to offer for sale only those brands of products sponsored by the defendant which were competitive with

27115 F. Supp. at 317. The parties had stipulated that the only question to go to the jury was whether the defendants had violated the antitrust laws, and since this discussion was in a ruling on a motion for judgment notwithstanding the verdict for the defendant, it was dictum. The same question, however, was later hitigated in Melrose Realty Co. v. Loew's, Inc., 234 F.2d 518 (3d Cir.), cert. denied, 352 U.S. 890 (1956), where the court followed the Harrison reasoning in disposing of the case.

28224 F.2d 678 (2d Cir. 1955), cert. denied, 350 U.S. 936 (1956).

29224 F.2d at 679.

30 Ibid.

31 147 F. Supp. 907 (D. Mass. 1956).

y2 147 F. Supp. at 909.

\$3 221 F.2d 358 (9th Cir. 1955). 
that of the plaintiff. The plaintiff was not itself in the business of distributing its product to retailers, but rehed on independent distributors. Therefore, the plaintiff was a supplier of the businesses directly affected by the defendant's violation. In holding that the plaintiff was nevertheless entitled to bring a section 4 action, the court reasoned that the violation alleged was "aimed" at the plaintiff because "aimed" at the product it manufactured. ${ }^{34}$ Under this reasoning, the parties were competitors and the plaintiff's loss was therefore "direct." 35 For this reason, the case is distinguishable from Snow Crest, because the product manufactured by the plaintiff in that action was not the same as that of the directly affected customer. ${ }^{30}$

\section{Loss of Employment}

Because the employer had been driven into bankruptcy by the defendant, an employee attempted to recover treble damages for his loss of einploymnt in Gerli v. Silk Ass' $n$ of America. ${ }^{37}$ By deciding that an officer of a corporation has no property interest in his office ${ }^{38}$ and that, for the purpose of section 4 , he has no business other than that of his employer's, the court concluded that no "injury" within the meaming of section 4 was shown. Since an employee, at the same time he is carrying out his master's business, is pursuing his personal objective of earning a livelihod, this reasoming amounts to an application of the "direct injury" rule. A second attempt to recover for a loss of employment from the same cause was made in Westmoreland Asbestos Co. v. Johns-Manville Corp. ${ }^{30}$ But instead of seek-

34 Karseal and Snow Crest are perhaps distinguishable for another reason. The defendant in Karseal reasonably should have known that its restraint would unquestionably affect the manufacturers of the excluded brands. On the other hand, the defendant in Snow Crest, without actual knowledge of the requirements contract, perhaps could not be expected to foresee the loss to a supplier of a component of the competitor's product. It would therefore be possible to argue that the result in Snow Crest is justified because recovery under Section 4 should be restricted to foreseeable plaintiffs. Cf. Comment, 51 Nw. U.L. REv. 141 (1956). Where a defendant was consciously violating the antitrust laws and taking lis chances with respect to treble damage awards under Section 4, to make the availability of Section 4 dependent on the violator's awareness of the extent to which his conduct is injurious is untenable. Where this is not the case, however, an adaptation of a rule used to fix the limit of tort liability for negligent acts which cause unintended injuries has some justification. The complexity of modern business, and the uncertainty of apphication of the antitrust laws has created a situation where it is frequently necessary for businesses to view as a legitimate business risk the possibility of a course of action later being adjudged an antitrust violation. A foresecable plaintiff rule would be one way of alleviating the harshness of the treble damage provision of Section 4 in cases where punitive damages do not seem appropriate. However, awarding treble damages to a clearly foresecable plaintiff may be equally harsh for the same reason. The difficulty is that a court has no discretion with regard to awarding such damages.

35 It should be noted, lowever, that there is considerable authority to the effect that the firms which distributed the plaimtiff's product also were entitled to bring a treble damage action. See text at notes 67 and 68 infra.

${ }^{36}$ Despite the connection between the volume of business of a customer and of a supplicr having a requirements contract, a restraint of the customer's trade is not a restraint of the supplier's, where they trade in different products. An argument to the contrary overlooks the distinction between a "direct" and "indirect" loss, namely that the latter is one step removed from the antitrust violation, and derivative of it. On the other hand, it is arguable that the plaintiff in Snow Crest was in reality a competitor of the defendant soft-drink manufacturer because the plaintiff's product was the principal ingredient of the soft drink produced by its customer.

3736 F.2d 959 (S.D.N.Y. 1929).

38 See Corey v. Boston Ice Co., 207 Fed. 465 (D. Mass. 1913) (action by deposed director). 3930 F. Supp. 389 (S.D.N.Y. 1939), aff'd per curiam, 113 F.2d 114 (2d Cir. 1940). 
ing to recover for the loss of the benefit of his bargain, the employee-plaintiff in this case alleged that his damages consisted of the value of property which he lost because unable to keep up the mortgage payments on it. This was disposed of on the ground that the proximate cause of the loss alleged was not the antitrust violations of the defendant.

Quite a different problem is presented where an attempt is made to recover treble damages for a denial of eniployment or discharge asserted to be itself a violation of the antitrust laws. This situation was before the Supreme Court in Radovich v. National Football League. ${ }^{40}$ Radovich was a professional football player who had broken the reserve clause in his contract with the Detroit Lions of the National Football League, to play for the Los Angeles Dons of the rival All-American Football Conference. Later, the defendant prevented him from obtaining a position as player-coach with the San Francisco Chppers, a team in a league affiliated with the defendant. He alleged that the Clippers would have hired him but for warnings from the defendant that he was blacklisted and any team signing him would suffer severe penalties. The blacklisting was alleged to be the result of a conspiracy to monopolize commerce in professional football. The circuit court affirmed a dismissal for failure to state a claim for which relief could be granted. It reasoned first that professional football was exempt from the operation of the antitrust laws for the same reason that organized baseball was. ${ }^{41}$ Second, it concluded that even if this were not so, the plaintiff had failed to state a claim. Its reason for this was that "within the four corners of the complaint, we doubt that the alleged means, restraint by the reserve clause and its enforcement, is legally sufficient to support, without more, a conclusion that these means were calculated to prejudice the public or unreasonably restrain interstate commerce." 42

On certiorari for the purpose of "determining whether the business of football comes within the scope of the Sherman Act," the Supreme Court, Mr. Justice Clark writing the opinion, reversed the decision on botl grounds. As to whether the complaint stated a claim, the circuit court's reasoning was rejected without discussion. Discussion was not necessary because:

\begin{abstract}
Petitioner's claim need only be "tested under the . . . Act's general prohibition on unreasonable restraints of trade" .... and meet the requirement that petitioner has thereby suffered injury. Congress has, by legislative fiat, determined that such prohibited activities are injurious to the pubhic and has provided sanctions allowing private enforcement ... by an aggrieved party. These laws protect the victims of the forbidden practices as well as the public ... this Court should not add requirements to burden the private hitigant beyond what is specifically set forth . . . in those laws. 43
\end{abstract}

In view of the court's disposition of the case, it was apparently satisfied that Radovich had alleged an "injury" within the meaning of section 4.

What the injury was remams to be determined. Since Radovich was only an individual player, it canot be said that he was in competition with the teams comprising the National Football League. Therefore, unless the team which refused to hire him in compliance with the warning from the defendant was itself a violator of the antitrust laws, Radovich's loss was "indirect." As this team was named as one of the defendants, it can be assumed that the loss was "direct." The reasoning

\footnotetext{
40352 U.S. 445 (1957).

41 Radovich v. National Football League, 231 F.2d 620, 622 (9th Cir. 1956).

42231 F.2d at 623 .

48352 U.S. at 453-54.
} 
of the circuit court, however, was that the antitrust violations were not "aimed" at Radovich, but rather at the rival league. This was based on the express assumption that the use of the reserve clause, and blacklisting those who violated it, was not an antitrust violation. Consequently, "if he is to recover at all, it is more probable that his must be a derivative right springing from the allegations of intent to boycott and ruin the All America Conference." ${ }^{44}$ If this assumption was correct, and the only violation was "aimed" at the rival league, then the "directly aimed" test was implicitly overruled by the Supreme Court.

But Mr. Justice Clark seems to have inferred that Radovich's injury consisted of a restraint of his trade, insofar as the blacklisting deprived him, in his business of earning a livelihood, of an employment opportunity. In discussing whether Radovich's complaint stated an injury to him, Mr. Justice Clark cited Mandeville Island Farms, Inc. v. American Crystal Sugar Co.45 In that case, an agreement between refiners to pay uniform prices for sugar beets was expressly held to be, for the purpose of determining the sufficiency of the allegations, a restraint of the beet growers' trade. The growers were seeking to recover treble damages under section 4 on account of the unreasonably low prices which they contended they were forced to accept for their beets as a result of this agreement. The reserve clause-for the breach of which Radovich was blacklisted-prolibits a player from signing with another club for the next playing season without the consent of the club holding his contract. At the same time, this club is not itself obligated to rehire the player for the period in question. Needless to say, unless each of the competing teams agree to abide by the reserve clauses in the contracts held by the other teams, this device would be largely ineffective. The effect of the implicit agreement of the teams to respect the reserve clauses is therefore precisely the same as that of the agreement complained of in Mandeville -it puts the injured party in a less favorable bargaining position with respect to the price he is able to command for what he has to sell. Clearly, the reserve clause in Radovich's contract was "aimed" at him, and the blacklisting was a sanction imposed for his breach of it. Consequently, rather than having overruled the "directly aimed" test, the Radovich decision would seem to have affirmed it.

For the same reason, Conference of Studio Unions v. Loew's, Inc.40 does not appear to have been overruled. In this case, the individual plaintiffs, members of the plaintiff union, were seeking to recover treble damages on account of their discharge by the "major" motion picture producers. The employees alleged that they were fired as the price for a rival union's participation in a conspiracy to destroy a competing group of producers known as the "independents." This object was to be accomplished, so the complaint stated, by the rival union supplying all its skilled workers to the "majors," thus leaving only unskilled workers available to the "independents." The court stated that although the discharge of the employees may have been in execution of a conspiracy in restraint of trade, it was not itself a violation of the antitrust laws entitling the employees to recover treble damages under section 4 , because the conspiracy was not "aimed" at them. Insofar as the discharges were not alleged to have as a purpose the lowering of wages which would amount to a restraint of the employees trade, this conclusion would seem correct.

44231 F.2d at 623 .

45334 U.S. 219 (1948).

46193 F.2d 51 (9th Cir. 1951). 
THE CONGRESS DECISION: A RIGHT TO BENEFITS TEEORY

While the Radovich decision may not have held that all "indirect" losses were recoverable under Section 4 , it did require that the section be liberally construed..$^{47}$ Consequently, if a loss is such that it indicates that a right vested in the plaintiff by the antitrust laws has been violated, recovery of treble damages can no longer be barred by application of the "direct injury" rule. Under the "direct imjury" rule, it was unnecessary to determine whether, in the case of an "indirect" loss, an "injury" was shown because even if it were, recovery was not permitted. Now that this rule cannot be used to dispose of actions for recovery of "iudirect" losses, the question of what private rights are created by the antitrust laws can no longer be avoided.

In Congress, the court was well aware that in order to dispose of the case this question had to be answered. The violation alleged was that the plaintiff's motion picture theater had been relegated to an inferior exhibiting position as part of a conspiracy between the lessee of the theater and various film distributors to monopolize film exhibition in the Chicago area. Under the lease, rentals were to consist of a percentage of gross receipts in excess of a guaranteed mininum rental. Plaintiff-lessor contended that because gross receipts and thereby the rentals would have been greater under competitive conditions, it was "injured" within the meaning of Section 4 and was therefore entitled to recover treble damages for this loss.

An antitrust violation can be "amied" at more than one area of the economy. The primary purpose of the conspiracy alleged in Congress was to control admission prices at the theaters operated by the lessee. To this extent, the conspiracy was "aimed" at the potential customers. But the facts alleged imply that a second objective of the lessee-one to be achieved by its control over the allocation of motion picture runs to its theaters-was to reduce its costs. Under the terms of the lease, the cost of leasing the plaintiff's theater was variable. Assuming the theater was suitable for the exhibition of first runs, it was apparently cheaper for the lessee to keep down the gross receipts at the plaintiff's theater and exhibit the first runs at another theater instead. Under the "directly aimed" test, then, the conspiracy was also "aimed" at the plaintiff.

It does not necessarily follow fron this that the plaintiff was "injured" within the meaning of Section 4. The conspiracy in Conference was "aimed" at the discharged employees as well as the competing film producers. But as their discharge was held not itself an antitrust violation, they were not entitled to recover treble damages under Section 4, even though they may have had a cause of action for wrongful discharge. But the lessor in Congress was not complaining of an act collateral to a restraint of trade. Rather, the conduct causing the loss for which recovery was souglit was the lessee's restraint of the trade at the plaintiff's theater.

Consequently, if this conduct violated a legal right vested in the plaintiff by the antitrust laws, then the plaintiff was "injured." The plaintiff's loss was not incurred in a business, unless receiving rent can be characterized as a business, and to say that the plaintiff was "injured" because its "trade" was restrained seems far-fetched. However, the allegations of a conspiracy to divert patronage, and thereby rentals, can be regarded as a tort to the lessor's reversion. And because this injury to property was also an antitrust violation, the plaintiff was

47 See text at note 43 stepra. 
entitled to recover treble damages under Section $4.48 \mathrm{~A}$ reduction of rentals by a diversion of gross receipts, if caused by the lessee acting in bad faith, has been held to be a tort. ${ }^{49}$ However, the only diversion alleged was that rentals were "kept down." But the proximate cause of the failure to receive greater rentals could be proven to be the lessee's unwillingness to exercise its right, under Section 16 of the Clayton Act, ${ }^{50}$ to enjoin a restriction on gross receipts to which it had consented. True, denying "first-runs" to a theater which apparently never had them is not so clearly a gain to the lessee at the lessor's expense, indicating the necessary bad faith, as a straight reduction of rentals. But the plaintiff's allegation implies that the lessee intended to keep down the gross receipts and thereby rentals. Since a failure to realize gain, if caused by an antitrust violation, can be an "injury" within the meaning of Section 4, this would seem an ample assertion of bad faith for the purpose of ruling on the sufficiency of the pleadings.

This was not the approach taken by the court. It regarded the issue to be whether a lessor was entitled to complain of an antitrust violation by a lessee who was free to manage the theater as it saw fit, not whether such freedom included a right to divert rentals. In concluding that the lessor did have a right to complain, the court reasoned that by agreeing that part of the rent be determined by gross receipts, the plaintiff "accepted ... a share of the risks of the [lessee's] business ... [and therefore was] entitled to rely on statutory remedies whose purpose is to reduce such risks." 51 The court then went on to say:

[T]he lessor is not asserting mismanagement by the lessee ... but rather that the lessee in conjunction with others conspired to and did violate the antitrust laws to the plaintiff's injury. Surely the fact that the operation of the theater was entrusted to the discretion of the lessee does not give the lessee the right to flaunt the antitrust laws, nor can we see why this fact should deny plaintiff the protection of and the right to rely on statutory remedies provided by the antitrust laws. ${ }^{52}$

On this reasoning, the plaintiff could recover under Section 4 whether or not the lessee was responsible for its loss. This is implicit in the court's reasonimg that the right to recover under Section 4 was due to the plaintiff's accepting a share of the risks of the lessee's business. The loss for which recovery was sought was "indirect" - that is, it was due to the effect of the violation on the lessee's gross receipts. Since one of the risks of the lessee's business was that its competitors might form a conspiracy with the film distributors of the kind complained of, such a loss could obviously occur even though the lessee were not itself a gnilty party. This possibility was recognized by the court, but it refrained from deciding that the plaintiff could neverthelss maintain a Section 4 action. ${ }^{53}$ The court thought that if both

48 Chattanooga Foundry and Pipe Works v. City of Atlanta, 203 U.S. 390 (1906). The injury for which recovery was sought was the amount paid in excess of a reasonable value for pipe, as a result of the fraud of the members of a trust, who arranged in advance the outcome of a "competitive" bidding.

49 Garden Suburbs Golf \& Country Club, Inc. v. Pruitt, 156 Fla. 825, 24 So.2d 898 (1946); Selber Bros., Inc. v. Newstadt's Shoe Stores, 203 La. 315, 14 So.2d 10 (1943); Goldberg 168-05 Corp. v. Levy, 170 Misc. 292, 9 N.Y.S.2d 304 (Sup. Ct. 1938), affirmed, 256 App. Div. 1086, 11 N.Y.S.2d 315 (1939).

5038 STAT. 737 (1914), 15 U.S.C. $\$ 26$ (1952).

51246 F.2d at 593.

52 Ibid.

53 Since the lessee could mamtain a treble damage action regardless of whether it was a member of the conspiracy, to condition the plaintiff's right of recovery on the status of the lesseo would seem untenable. 
lessor and lessee could sue, there might be a problem of apportioning damages, or settlement by one without the consent of the other. These problems would arise if the lessee, in its action, was entitled to recover not only the additional net profits it would have earned under competitive conditions, but also the lessor's percentage of the greater volume of gross receipts necessary for the realization of those profits. As the lessee normally would not seem entitled to recover lost gross receipts, ${ }^{54}$ a simpler approach would be to allow recovery only for what the party bringing the action was entitled. The lessor, to recover for its loss, would then have to bring a separate suit, but the problems which troubled the court would then have been eliminated.

Returning to the court's statement that the plaintiff accepted a share of the risks of the lessee's busmess, it should be noted that the risks were "shared" only in the sense that the return to the lessor, as well as to the lessee, was dependent on the gross receipts of the theater. In other words, just as the loss for which recovery was sought was "indirect," so also was the manner in which the plamtiff shared in the risks of the lessee's business. This "share of the risks" reasoning therefore implies that the antitrust laws have created a right to the benefits - "indirect" as well as "direct"- to be derived from the conditions which they are designed to ensure. The impact of this theory on the question whether recovery under Section 4 of other kinds of "indirect" loss should be allowed needs to be examined.

Clearly, if a corporation is entitled to recover under Section 4 for lost profits, a stockholder should not be allowed to bring an individual action for his share of them. ${ }^{65}$ His remedy, if the corporation refuses to bring the action, is a derivative suit. ${ }^{50} \mathrm{~A}$ more difficult question is whether the stockholder should be allowed to recover for a loss in the value of his stock. Not unless the corporation is driven out of business can any such loss be said to be permanent. This is particularly true because of the right of the corporation, under Section 16 of the Clayton Act, to enjoin the continuance of the activities which are the cause of its decline in earning power. But if the corporation is forced into bankruptcy and liquidated, the loss to the stockholders clearly attributable to the antirust violation ${ }^{57}$ would be the difference between what the net per-share amount of capital and surplus would lave been if the corporation had not been injured, and the amount to which it was reduced because of the violation. However, these losses differ from lost profits only in that the former measure decreases in the stockholders' equity, while the latter

54 Productive Inventions, Inc. v. Trico Products Corp., 224 F.2d 678 (2d Cir. 1955), cert. denied, 350 U.S. 936 (1956) (dictum) ; but cf. Hempstead Theater Corp. v. Metropolitan Playhouses, Inc., 308 N.Y. 712, 124 N.E.2d 332 (1954) (amount received by lessee in settlement of treble damage suit held to be gross receipts for purpose of ruling on a demurrer to a percentagelessor's action for a share). To allow recovery of gross receipts in a treble damage action would create a windfall, because the costs otherwise necessary for their realization would not have been incurred. That is, it can hardly be said that one of the benefits to be derived from conditions of free competition is the realization of revenues without having to incur any costs.

55 See text following note 16 supra.

to Formerly, stockholder's derivative antitrust suits were barred on the ground that the action lay only in equity, United Copper Securities Co. v. Amalgamated Copper Co, 244 U.S. 261 (1917), where to allow it would deprive the defendant of his right to a jury trial, Fleitmann v. Welsbach Street Lighting Co., 240 U.S. 27 (1916). Rule 2 of the Federal Rules of Civil Procedure, however, has been held to eliminate this procedural obstacle. Fanchon \& Marco, Inc. v. Paramount Pictures Corp., 202 F.2d 731 (2d Cir. 1953).

67 The amount by which the price paid on the open market exceeded the book value of stock would to an uncertain extent constitute discounted future growth. It is lighly unlikely that a figure as speculative as this-witness the daily market fluctuations-would be recoverable. 
are unrealized increases. ${ }^{58}$ Unless the right to recover for such losses is vested in the corporation the shareholders would recover ahead of the creditors of the corporation. But suppose the full amount of the recovery under Section 4 for a bankrupt corporation was necessary to satisfy debts, leaving nothing for the stockholders. Clearly in purchasing stock a person accepts a share in the risks of the corporation, and just as clearly the antitrust laws are designed to reduce the risk of being driven out of business. Under the "benefits" theory, therefore, the conclusion is inescapable that the stockholders of a liquidated corporation would be entitled to recover treble the book value their equity would have had if the corporation had not been injured, offset only by the amount of any liquidation distribution.

With regard to losses of a creditor, a similar situation exists. Denial of actions to recover under Section 4 for such losses was considered by the court to be necessary to prevent an individual creditor from gaining a preference over other creditors of an imsolvent business in contravention of the policy of the bankruptcy laws. This assumes that a creditor cannot recover in his own right, and that an action by him would be one to reach an asset of the debtor. But to the extent that the likelihood of a business paying its debts is dependent on its prospects, a person loaning money to a firm is sharing indirectly in its risks. That the amount of the claim is not determined by the size of the debtor's gross receipts would seem immaterial, for an antitrust violation may not only depress gross receipts, but also make them insufficient to cover costs. Should this occur, the payment of either kind of claim in full becomes impossible. In such a case, the amount of the deficiency is a loss of a benefit which would have been obtained if the conditions intended by the antitrust laws had prevailed. Until the business becomes bankrupt, the loss to the creditor is not permanent. But at this point, if a recovery under Section 4 for the injury to the business is insufficient to pay their claims in full, the creditors would appear entitled to recover treble damages for the deficiency. To deny them recovery would be to make a distinction between a failure to recover the cost of an asset used in a business, for which recovery has been allowed, ${ }^{60}$ and the failure of a creditor of that business to recover full payment on his claim. This would be inconsistent with a right to the "indirect" benefits to be derived from the conditions the antitrust laws are designed to ensure.

An employee clearly shares indirectly in the risks of his employer's business, since the decision whether the position which he holds should remain filled is based on the employer's prospects. Should he lose his job because these prospects are adversely affected by an antitrust violation, he would be "injured" under the benefits theory. Since his discharge was the result of a wrongful act, or series of acts, it would seem that his damages should be the same as if he had been wrongfully discharged by his employer. ${ }^{60}$

Under the "benefits" theory, treble damages would also be recoverable for the indirect loss of profits of a supplier. His sales are a function of the gross receipts of the customer, since a curtailment of the customer's own sales will result in a reduction of his purchases from supphers. Therefore, a supplier shares in the risks

58 See note 14 supra.

50 Story Parchment Co. v. Paterson Parchment Paper Co., 282 U.S. 555 (1931).

60 If, however, the employee is wrongfully discharged by his employer, as in Conference, even under the "benefits" theory he would have to show that the discharge was itself a violation of the antitrust laws. But it would seem that a dischcarge-say, of an usher at the plaintiff's theatre-which is not wrongful except insofar as it is due to a self-inflicted reduction of business as part of a conspiracy in restraint of trade, would give rise to a Section 4 action. 
of the customer's business to the same extent as does a person entitled to a percentage of gross receipts. But in addition to the proof required to recover for the failure to receive more income from a claim to a percentage of gross receipts, it would be necessary to show that the customer would have placed its additional orders with the suppher seeking to recover. With respect to the sufficiency of the allegations, both the Karseal and Snow Crest cases satisfied this requirement. In Karseal, the customers whose business was affected by the defendant's violations were distributors to retailers of the product manufactured by the plaintiff. In Snow Crest, the directly affected business was contractually obligated to buy all of the syrup for its soft drink from the plaintiff.

The significance of this "benefits" theory is apparent. Because the court in Congress stressed the fact that the lessee was a member of the conspiracy complained of, it cannot be said to have relied solely upon the "benefits" theory. ${ }^{61}$ Yet it is implicit in the court's reasoning in reversing the judgment below, which held that no "injury" within the meaning of Section 4 was made out. This "benefits" theory, however, is not the same as the "directly aimed" test. Since the latter was not overruled by Radovich, and in fact best explains that decision, it is necessary to examine the manner in which it differs from the "benefits" theory.

\section{A RIGHT TO PROTECTION THEORY}

According to the "directly ained" test, only those persons at whom an antitrust violation is "aimed" are "injured" within the meaning of Section 4. Although none of the cases using this test state why no right created by the antitrust laws is violated in the case of a "remote" loss, taken together, an answer appears. In Karseal, it will be recalled, a violation by a distributor to retailers of automobile finishes was held to be "aimed" at a inanufacturer of an excluded brand, even though the manufacturer used independent distributors. At the other extreme is the Conference case, where the court held that an antitrust violation which motivated the discharge of the employees seeking to recover was not "aimed" at them because not a restraint of their trade. Since the violation in Karseal was considered to be a restraint of trade in the plaintiff's product, these two cases stand for the proposition that a person is injured within the meaning of Section 4 when his trade is restrained.

From this it follows that the right created by the antitrust laws, with respect to restraints of trade, is not a right to the benefits to be derived if such restraints are prevented, but a right to protection from the acts which they probibit. The acts made illegal - such as restraints of trade-are stated in terms of their impact on others. Consequently, only those who are affected by activities in a manner that is prohibited by the antitrust laws are "imjured" within the meaning of Section 4.

61 Despite the language quoted at note 52 supra, the court apparently felt that the action should be allowed because there was an impermissible diversion of rentals. This was the reason given on petition by the distributors for a rehearing for dismissing their contention that they had a right to rely on the requests for pictures received from the lessee. But the court gave no consideration whatever to the question whether bad faith on the part of the lessee was shown, which is necessary for a common law diversion to be actionable. Suppose the lessee's purpose with respect to the plaintiff's theater had not been to reduce overall costs by reducing the rent, but to maximize its profits at all the theaters through control of admission prices. The importance of showing bad faith is indicated by Dickey v. Philadelphia Minit-Man Corp., $377 \mathrm{~Pa}$. 549, 105 A.2d 580 (1954), in which the court held that under a lease like that in Congress, unless bad faith is shown, the good faith business judgment rule applies with regard to management decisions affecting gross receipts. 
Under this "right to protection" theory, an "indirect" loss due solely to the fact that the person sustaining it "shared" in the risks of the directly affected business would not be recoverable under Section 4. Since the Radovich decision is consistent with the "directly aimed" test, it would seem to support the "right to protection" theory. Consequently, the results as distinguished from the reasoning, of the cases applying the "direct injury" rule-except perhaps Harrison" ${ }^{62}$-do not appear to have been overruled by Radovich. ${ }^{63}$

Besides Congress, only the Camrel case ${ }^{64}$ and three other district court decisions $^{65}$ support the "benefits" theory. The "sales agent" cases, which the court in Congress thought supported its "share of the risks" reasoning, in actuality serve to indicate when the "right to protection" arises. The first of these was Roseland v. Phister $M f g . C o .,{ }^{66}$ in which the plamtiff was complaining of an agreement between his supplier and its competitor under which the market for their products was divided between them. As a result, the plaintiff was deprived of an opportunity to submit bids for his supplier's product in the other manufacturer's "territory." He was seeking to recover treble damages for the loss of commissions on sales wlich he asserted he otherwise could have obtained. The court held that because he was engaged in a business separate from that of his supplier, his complaint made out an "injury" within the meaning of Section $4 .{ }^{.77}$ He was "injured" because of the restraint of his trade, not because of the loss to him as a result of the restraint of his supplier's trade. ${ }^{68}$

It is arguable that the "right to protection" theory creates an unwarranted distinction between those who have dealings with the victim of an antitrust viola-

62 Before resorting to the "direct injury" rule, the court in Harrison first decided there was no violation of a duty owed by a lessee to his landlord. But it does not appear from the opinion what the specific allegations of the complaint were. Therefore, whether bad faith was sufficiently alleged cannot be determined.

63 With regard to whether the Snow Crest decision is inconsistent with Radovich, sce note 36 supra.

64 See text following note 24 supra.

65 Tower Bldg. Corp. v. Loew's, Inc, $1956 \mathrm{CCH}$ Trade Cas. Par. 68,537 (lessor of theater). The court in Congress cited two other cases. One, an unreported 7th Circuit decision, was 1617 Belmont Co. v. Columbia Pictures Corp., No. 52-c-251. The other was East Orange Amusement Co. v. Vitagraph, Inc., CCH Trade Cas. Par. 52,965 (D. N.J.). This writer was unable to locate the East Orange case either at the citation given, or elsewhere.

66125 F.2d 417 (7th Cir. 1942).

${ }^{67}$ Accord, Vines v. General Outdoor Advertising Co., 171 F.2d 487 (2d Cir. 1948); Klcin v. Sales Builders, Inc., 1950 CCH Trade Cas. Par. 62,600 (N.D. Ill.) ; McWhirter v. Monroe Calculating Mach. Co., 76 F. Supp. 456 (W.D. Mo. 1948). Miley v. John Hancock Mut. Life Ins. Co., 148 F. Supp. 299 (D. Mass.), af'd per curiam, 242 F.2d 758 (1st Cir. 1957), is distinguishable, because the broker bringing the action made no claim to have been entitled to any commission for securing the insurance contract which he alleged would have been obtained but for the defendants' antitrust violations. The basis for the dismissal was that the damages alleged were speculative.

68 The position of the plaintiff in Roseland is comparable to that of the distributors marketing the auto finish of the plaintiff in Karseal, and the two cases together stand for the proposition that all those who trade in a particular product can recover under Section 4 for a restraint of its trade.

To be distinguished, however, is the situation where a distributor is forced to pay higher than reasonable prices for a product, but is able to pass this additional cost on to the ultimate consumer. In this case, there is no mjury because there is no loss. Feddersen Motors, Inc. v. Ward, 180 F.2d 519 (10th Cir. 1950); Clark Oil Co. v. Phillips Petroleum Co., 148 F.2d 580 (8th Cir.), cert. denied, 326 U. S. 734 (1945) ; Northwestern Oil Co. v. Socony-Vacuum Oil Co., 138 F.2d 967 (7th Cir. 1943), cert. denied, 321 U.S. 792 (1944). 
tion and those who deal directly with the violator. The Camrel decision, where a lessor was unable to renew its lease on more advantageous terms because the lessee was a victim of a restraint of trade, is incorrect under this theory. But because of the additional factor that the lessee in the Steiner case was the violator, its result is supportable. This would seem to indicate that a person's right to recover under Section 4 is conditional on his being a foreseeable plaintiff. ${ }^{69}$ But this criticism assumes that the lessor in Camrel, as well as the one in Steiner, was "injured." In Steiner, however, the coercive bargaining power of the tenant was alleged to be due to its monopoly of film distribution, which deprived the plaintiff of any alternative to accepting the tenant's terms. This constituted a restraint of trade of the lessor in its business of leasing. On the other hand, the only restraint in Camrel was one affecting not the plaintiff, but the lessee. Consequently, the distinction between the two cases is that no restraint of the lessor's trade was made out by the allegations in Camrel, not that the plaintiff in that case was unforeseeable.

\section{CONCLUSION}

The answer which the "directly aimed" test provides to the question of what private rights are created or protected by the antitrust laws, such that a loss due to their violation is recoverable under Section 4, is considerably inore precise than that given by the "benefits" theory. The antitrust laws do not indicate what benefits they are intended to provide, except by implication. Rather, they prohibit certain kinds of activities. Hence the "benefits" theory has little relation to their substantive provisions. The "right to protection" theory, by contrast, requires that in order to recover under Section 4 the plaintiff inust show that he has been affected in a manner prohibited by the provisions of the antitrust laws. This theory can hardly be said to curtail the protection afforded by these laws. Moreover, the "right to protection" theory of interpreting Section 4 would prevent windfall recoveries under its treble damages provision.

Section 16 of the Clayton Act, which allows injunctive relief in a private action, uses the words "threatened loss or damage," rather than the words "threatened injury." 70 This implies that it is not restricted in its availability to those persons who would be entitled to bring an action under Section 4 for treble damages. ${ }^{71}$ If this statute were interpreted so as to be available to anyone who would suffer as a result of an antitrust violation, the problem of protecting persons to whoin Section 4 is not available would be solved.

Marvin M. Grove

69 See note 34 supra.

7038 Stat. 737 (1914), 15 U.S.C. \$ 26 (1952).

71 No case bas been found which discusses whether Section 16 has a broader coverage than Section 4, nor has one been found which allowed an action under Section 16 to a party not entitled to bring an action under Section 4. 